World Scientific Proceedings Series on

Computer Engineering and Information Science 3

\title{
Computational Intelligence in
} Business and ECOnOmics Conference 
World Scientific Proceedings Series on Computer Engineering and Information Science

Series Editor: Da Ruan (Belgian Nuclear Research Centre $(S C K \cdot C E N)$ $\mathcal{E}$ Ghent University, Belgium

Vol. 1: Computational Intelligence in Decision and Control edited by Da Ruan, Javier Montero, Jie Lu, Luis Martínez, Pierre D'hondt and Etienne E. Kerre

Vol. 2: Intelligent Decision Making Systems edited by Koen Vanhoof, Da Ruan, Tianrui Li and Geert Wets

Vol. 3 Computational Intelligence in Business and Economics edited by Anna Gil-Lafuente and José M. Merigó 
World Scientific Proceedings Series on

Computer Engineering and Information Science 3

\section{Computational \\ Intelligence in}

Business and

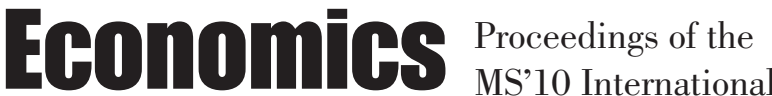

Conference

Barcelona, Spain $\quad 15-17$ July 2010

editors

Anna M. Gil-Lafuente

University of Barcelona, Spain

José M. Merigó

University of Barcelona, Spain 


\section{Published by}

World Scientific Publishing Co. Pte. Ltd.

5 Toh Tuck Link, Singapore 596224

USA office: 27 Warren Street, Suite 401-402, Hackensack, NJ 07601

UK office: 57 Shelton Street, Covent Garden, London WC2H 9HE

\section{British Library Cataloguing-in-Publication Data}

A catalogue record for this book is available from the British Library.

\section{World Scientific Proceedings Series on Computer Engineering and \\ Information Science - Vol. 3 \\ COMPUTATIONAL INTELLIGENCE IN BUSINESS AND ECONOMICS \\ Proceedings of the MS'10 International Conference}

Copyright (C) 2010 by World Scientific Publishing Co. Pte. Ltd.

All rights reserved. This book, or parts thereof, may not be reproduced in any form or by any means, electronic or mechanical, including photocopying, recording or any information storage and retrieval system now known or to be invented, without written permission from the Publisher.

For photocopying of material in this volume, please pay a copying fee through the Copyright Clearance Center, Inc., 222 Rosewood Drive, Danvers, MA 01923, USA. In this case permission to photocopy is not required from the publisher.

ISBN-13 978-981-4324-43-4

ISBN-10 981-4324-43-4

Printed in Singapore. 
The MS'10 Barcelona International Conference is supported by
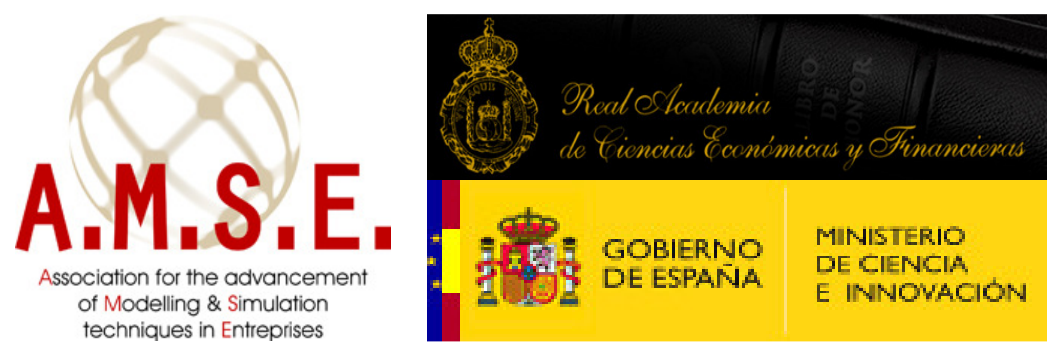
This page intentionally left blank 


\section{PREFACE}

The Association for the Advancement of Modelling \& Simulation Techniques in Enterprises (AMSE) and the University of Barcelona are pleased to present the main results of the International Conference of Modelling and Simulation in Engineering, Economics and Management, held in Barcelona, 15 - 17 July, 2010, through this Book of Proceedings published in the Book Series "World Scientific Proceedings Series in Computer Engineering and Information Science".

MS'10 Barcelona is co-organized by the AMSE Association and the University of Barcelona, Spain. It is co-supported by the Spanish Royal Academy of Financial and Economic Sciences and the Spanish Ministry of Science and Innovation. It offers a unique opportunity for researchers, professionals and students to present and exchange ideas concerning modelling and simulation and related topics and see how they can be implemented in the real world.

In this edition of the MS International Conference, we want to give special attention to the emerging area of Computational Intelligence. In particular, we want to focus on the implementation of these techniques in the Economic Sciences. Thus, the title of this book is "Computational Intelligence in Business and Economics". Computational Intelligence is a very broad research area that includes fuzzy set theory, neural networks, evolutionary computation, probabilistic reasoning and chaotic comuting as particular research topics of this discipline. The growing importance of Computational Intelligence in the Economic Sciences is obvious when looking to the complex world we are living in. Every year new ideas and products are appearing in the markets making them very flexible and with strong unpredicted fluctuations. Therefore, in order to deal with our world in a proper way, we need to use models that are able to assess the imprecision and the uncertainty.

MS'10 Proceedings is constituted by 88 papers selected from 141 submissions from 36 countries, making an acceptance rate of $62 \%$. We have also included a summary of the presentation given by the plenary speakers: Jaime Gil Aluja, Janusz Kacprzyk and Korkmaz Imanov. The book is divided in 7 parts: (1) Theoretical Foundations, (2) Accounting and Finance, (3) Management, (4) 
Marketing, Sports and Tourism, (5) Economics and Politics, (6) Applications in Engineering, and (7) Applications in Other Fields.

We would like to thank all the contributors, referees and the scientific and honorary committees for their kind co-operation with MS'10 Barcelona; to Jaime Gil Aluja for his role as the President of AMSE and the President of the honorary committee; to the whole team of the organizing committee, including Lluis Amiguet, Luciano Barcellos, Carolina Luis Bassa, Josefa Boria, Jaime Gil Lafuente, $\mathrm{M}^{\mathrm{a}}$ Carmen Gracia, Aras Keropyan, Pilar López-Jurado, Onofre Martorell, Carles Mulet, Camilo Prado, $\mathrm{M}^{\mathrm{a}}$ Luisa Solé and Emilio Vizuete; and to Chelsea Chin (Editor, World Scientific) for her kind advise and help to publish this volume. Finally, we would like to express our gratitude to World Scientific and in particular to Da Ruan (editor-in-chief of the book series "WS Proceedings Series in Computer Engineering and Information Science") for his support in the preparation of this book.

Anna M. Gil Lafuente, MS'10 Barcelona Chair.

José M. Merigó, MS'10 Barcelona Co-chair.

Barcelona, March 2010. 


\title{
HONORARY COMMITTEE
}

\begin{abstract}
Special thanks to all the members of the Honorary Committee for their support in the organization of the MS'10 Barcelona International Conference.
\end{abstract}

\section{President of the Honorary Committeee}

Jaime Gil-Aluja

President of AMSE and President of the Spanish Royal Academy of Financial and Economic Sciences

\section{Honorary Committee}

André Azoulay

Ernest Benach

Alessandro Bianchi

José Casajuana

Jacques Delruelle

Ricardo Díez Hotchleitner

Isidre Fainé Casas

Lorenzo Gascón

Mohamed Laichubi

Juan José Pinto

Dídac Ramírez

Eugen Simon

Lotfi A. Zadeh
Le Conselleir de Sa Majesté le Roi du Royaume du Maroc

President of the Parlament de Catalunya

Ex Rector of the University of the Mediterranean

Studies of Reggio di Calabria

President of the Royal Academy of Doctors

President of the Censor School of Accounting of Belgium's National Bank

Honorary President of the Club de Roma

President of La Caixa

Vicepresident of the Spanish Royal Academy of

Financial and Economic Sciences

Former Minister and Algerian Ambassador

Former President of Caixa Barcelona

Rector of the University of Barcelona

President of the National Foundation for the

Science and the Art of Romania

University of California at Berkeley 
This page intentionally left blank 


\section{SCIENTIFIC COMMITTEE}

Special thanks to all the members of the Scientific Committee for their kind support in the organization of the MS'10 Barcelona International Conference.

Christian Berger-Vachon

(Co-President)

Jihad M. Alja'am, Qatar

Said Allaki, Morocco

$\mathrm{M}^{\mathrm{a}}$ Teresa Anguera Argilaga, Spain

Noura Al-Khaabi, UAE

Jacques Marie Aurifeille, France

José Daniel Barquero, Spain

Pietro Burrascano, Italy

Fernando Casado, Spain

Houcine Chafouk, France

Nashaat El-Khameesy, Egypt

Kurt Engemann, USA

Farahat Farahat, Egypt

Joan Carles Ferrer, Spain

Fares Fraij, Jordan

Jaime Gil Lafuente, Spain

Federico González Santoyo, Mexico

Rainer Hampel, Germany

Francisco Herrera, Spain

Kedi Huang, P.R. China

Korkmaz Imanov, Azerbaijan

Janusz Kacprzyk, Poland

Yuriy Kondratenko, Uckraine

Viktor Krasnoproshin, Belarus

Prabhat Kumar Mahanti, India

Leonid A. Kuztnesov, Russia

Vicente Liern Carrión, Spain
Anna M. Gil-Lafuente

(Co-President)

Enrique López González, Spain

Jesús Marín Solano, Spain

Luis Martínez López, Spain

José M. Merigó Lindahl, Spain

Ramir Mirsalinov, Azerbaijan

Francesco C. Morabito, Italy

Vladimir S. Neronov, Kazakhstan

Ahmad Nuseirat, Jordan

Ahmed Oulad Said, Morocco

Witold Pedrycz, Canada

Emmanuel Perrin, France

Ramón Poch Torres, Spain

Joan Francesc Pont Clemente, Spain

José Antonio Redondo, Spain

Alfredo Rocafort, Spain

Alfonso Rodríguez, Spain

José Jaime Ronzón Contreras, Mexico

Da Ruan, Belgium

Mohamed Saighi, Algeria

Petr Sternbeck, Czech Rep.

Antonio Terceño, Spain

Jaime Tinto Arandes, Venezuela

Emili Vizuete, Spain

Iskander Yaacob, Malaysia

Ronald R. Yager, USA

Aladin Zayegh, Australia 
This page intentionally left blank 


\title{
ORGANIZING COMMITTEE
}

\author{
Special thanks to all the members of the Organizing Committee for their support \\ during the preparation of the MS'10 Barcelona International Conference.
}

\section{Chair of the Organizing Committee}

Anna M. Gil Lafuente, Chair MS'10 Barcelona

\section{Co-Chair of the Organizing Committee}

José M. Merigó Lindahl, Co-Chair MS'10 Barcelona

\section{Organizing Committee}

Lluís Amiguet Molina, Spain

Luciano Barcellos de Paula, Brazil

Josefa Boria Reverter, Spain

Jaime Gil Lafuente, Spain

$M^{a}$ Carmen Gracia Ramos, Spain

Aras Keropyan, Turkey

Pilar López-Jurado, Spain

Carolina Luis Bassa, Spain

Onofre Martorell Cunill, Spain

Carles Mulet Forteza, Spain

Camilo Prado Román, Spain

$\mathrm{M}^{\mathrm{a}}$ Luisa Solé Moro, Spain

Emili Vizuete Luciano, Spain 
This page intentionally left blank 


\section{ACKNOWLEDGEMENT TO REVIEWERS}

Special thanks to all the referees for their advice in the revision process of the papers submitted to the MS'10 Barcelona International Conference:

Latif Adnane

Gerardo G. Alfaro Calderón

Jorge de Andrés

Luciano Barcellos

Ahmed Benzaoui

Josefa Boria

José M. Brotons

Matteo Cacciola

Alain Calzadilla

Agusti Casas

M $^{a}$ Elvira Cassú

Omar Danilo Castrillón

David Ceballos

Edwin Dado

Rekioua Djamila

José Antonio Díaz

Djordje N. Dihovicni

Kurt J. Engemann

Elena Escrig

Aurelio Fernández

María José Fernández

Joan Carles Ferrer

Pedro Flores

Ever Angel Fuentes

Javier Garcia Fronti

Pablo García
Rosario Garza Ríos

Vasile Georgescu

Anna M. Gil Lafuente

Jaime Gil Lafuente

Egils Ginters

Jaime A. Giraldo

$\mathrm{M}^{\mathrm{a}}$ Carmen Gracia

Calin Gurau

Escid Hammoud

Rubén Huertas

Nazhad A. Hussein

Rozita B. Jailani

Shawnim R. Jalal

Mariano Jiménez

Jelena Jovanovic

Aras Keropyan

Magda Komornikova

Yuriy Kondratenko

Victor Krasnoproshin

Hocine Labar

Luisa Lucila Lazzari

Monica Leba

Salvador Linares

Bárbara Llacay

Carolina Luis Bassa

Aiyed Maree 


\section{CONTENTS}

Preface

vii

Anna M. Gil-Lafuente, José M. Merigó

$\begin{array}{lc}\text { Honorary Committee } & \text { ix }\end{array}$

Scientific Committee $\quad$ xi

Organizing Committee xiii

Acknowledgement to Reviewers $\quad$ XV

PLENARY SPEAKERS 1

The Scientific Research of a Future Sustainable Economic 3

Development

Jaime Gil Aluja

Decision Making, Decision Processes and Decision Support Systems

Janusz Kacprzyk

Imprecise Probability for Estimated Forecasting Variants of the

Economical Development

Korkmaz Imanov

PART 1: THEORETICAL FOUNDATIONS

The Induced Generalized OWAWA Distance Operator

José M. Merigó, Anna M. Gil-Lafuente

Probabilistic Modelling using Copula Functions based Bayesian

Approach

Pranesh Kumar 
On Hybridization of Probabilistic and Fuzzy Approaches to

Propagate Randomness and Epistemic Uncertainty in Risk Assessment Models

Vasile Georgescu

Structural Optimization of Linguistic Knowledge Base of Fuzzy

Controllers

Yuriy P. Kondratenko, Leonid P. Klymenko,

Eyad Yasin Mustafa Al Zu'bi

2G: A Classification Algorithm based on Pattern Recognition and

Decision Trees

María de Guadalupe Cota, Pedro Flores

A Tool for Objectives Definition in the MKDD Methodology for

Data Mining Studies

Anna M. Gil-Lafuente, Emilio Vizuete, Josefa Boria

Solution of Applied Problems: Formalization, Methodology and Justification

Victor Krasnoproshin, Vladimir Obraztsov, Herman Vissia

Optimal Planification of Bidimentional Tables with Fuzzy Numbers and Summatory Restrictions

Xavier Bertran Roure, Joan Bonet Amat,

Guillem Bonet Carbó, Salvador Linares Mustarós

Induced Generalized Aggregation Operators in the Probabilistic

OWAWA Operator

José M. Merigó

Functional Coordinates

Samir Zaki Mohamed Mehrez.

Easy Communication Environment for Distributed Simulation

Artis Silins, Egils Ginters, Dace Aistrauta 
Fuzzy Analysis for Assets Replacement

Federico González Santoyo, Beatriz Flores Romero, Juan J. Flores, Anna M. Gil-Lafuente, R. Chávez

Investigation and Scientific Evolution of Cost Accounting

Programmes

Alfredo Rocafort Nicolau, Francisco Martín Peña, José Daniel Barquero Cabrero

Claim Reserving with Fuzzy Regression and the Two Ways of ANOVA

Jorge de Andrés Sánchez.

Integrating Sustainability through Fuzzy Logic: Fortune Global 100

Sustainability Rating

Elena Escrig-Olmedo, Juana María Rivera-Lirio,

María Jesús Muñoz-Torres, María Ángeles Fernández-Izquierdo

Quality Evaluation of the Human Action Performing in a Working

System using Fuzzy Logic

Andreea Ionica, Monica Leba, Eduard Edelhauser

Main Factors to Mainstream Debt for Shaping Capital Structure in

Service, Trade, Transformation Construction Sectors, Mining

Industry and Telecommunications in Mexico

Juan Gaytán Cortés, José Sánchez Gutiérrez,

Joel Bonales Valencia

A Nanotechnology Joint Investment Framework

María Teresa Casparri, Javier Garcia Fronti

Origin and Diffusion of Direct Costing: Evolution or Scientific

Revolution?

Alfredo Rocafort 
Decision Making Techniques in a Unified Model between the

Weighted Average and the OWA Operator

José M. Merigó, Anna M. Gil-Lafuente

Realistic Agent-Based Simulation of Financial Crises: The 1998

Turmoil

Bárbara Llacay, Gilbert Peffer

Financial Relations of National Park Agencies in Latvia:

Opportunities for ICT and Dynamic Modelling

Iluta Berzina, Agita Livina

Duration and Uncertainty: A Comparative Analysis for Indexed Bonds Aurelio Fernández, María-José Garbajosa-Cabello, María-Belén Guercio

Introducing Fuzzy Numbers in the Study of the Viability of a

Treasury Forecast

Salvador Linares Mustarós, Joan Carles Ferrer Comalat, Elvira Cassú Serra, Dolors Corominas Coll

Validating the Pecking Order Theory in the Spanish Chemical Industry

Xavier Càmara-Turull, Xavier Borràs Balsells,

María Teresa Sorrosal Forradellas,

María Ángeles Fernández Izquierdo

Application of the Affinities Theory in a Problem of the Latin

American Business Competitiveness

Erika Anselín-Ávila, Anna M. Gil Lafuente

Modelling of the Economic Effect of Rotation and Financial

Levering in the Field of Profitability

Alfredo Rocafort Nicolau, Manuel Flores Caballero

A Business Intelligence Software Made in Romania: A Solution for

Romanian Companies during the Economic Crisis

Eduard Edelhauser, Andreea Ionica, Lucian Lupu-Dima 
Jesús Marín

Luis Martínez

Giuseppe Megali

Samir Mehrez

José M. Merigó

Sjoerd Mevissen

Francesco Carlo Morabito

Kelaiaia Mounia

Anna Petrickova

Ileana Pérez
Giselle Pino

Emil Pop

Camilo Prado

Toufik Rekioua

Alfredo Rocafort

S. Rominus Valsalam

Mohamed Saighi

Emilio Vizuete

Changfan Xin 
Algorithm Applied in the Identification of Stakeholders

Anna M. Gil-Lafuente, Luciano Barcellos Paula

Job Shop Problem Analysis through an Evolutionary Algorithm

Omar Danilo Castrillón, William Ariel Sarache, Jaime Alberto Giraldo

Searching for Entrepreneurial Excellence: An Approach to

ELECTRE II Philosophy

Giselle Pino León, Rosario Garza Ríos,

Ileana Pérez Vergara

Decision Support Model for Information Systems Integration in

Supply Chains: A Fuzzy Approach

Dania Pérez Armayor, José A. Díaz Batista

Analysis of Contract Flexibility by using Modelling and Simulation

Wendy Haddad Carraro, Joao Luiz Becker

Decision Making in Strategic Business Management

Aras Keropyan, Anna M. Gil-Lafuente

The Improvement of the Key Processes in a Terminal of Containers:

An Application of the Discrete Simulation

Ileana Pérez Vergara, Rosario Garza Ríos

Networking and Logistic Strategies Enacting Assembling Synergism

Raul O. Dichiara, Blanca I. Niel

Fuzzy Decision Making with Probabilities and Induced Aggregation

Operators

José M. Merigó, Kurt J. Engemann

Artificial Intelligence on the Routing Process Optimization

Omar Danilo Castrillón, Diana María Cardenas, Jaime Alberto Giraldo, Lina Eliana Ávila 
A Personnel Selection Model within the Strategic Human Resource Management Process using the Galois Group Theory Aras Keropyan, Anna M. Gil-Lafuente

Methods of Proximity for Personnel Selection through Competitions Rosario Garza Ríos, Ileana Pérez Vergara, Caridad González Sánchez.

Level of Influence of the Variables in the Process of the Knowledge Management: A Quantification over the Theory of Uncertainty Gerardo Gabriel Alfaro Calderón

\section{PART 4: MARKETING, SPORTS AND TOURISM}

The Selection of the Pilot Product Best Suited to a Target Segment Jaime Gil-Lafuente, Julio Rojas-Mora

The Use of Expertons for Complaint Handling in a CRM Strategy Anna M. Gil-Lafuente, Carolina Luis Bassa

A Model for Junior Football Players Valuation José M. Brotons

Choice of Market Entry Mode into a Foreign Market: The Case of 395 Balearic Hotel Chains in the Caribbean Region and Gulf of Mexico Onofre Martorell Cunill, Carles Mulet Forteza, Antonio Socías Salvá

Model for the Estimation of Variables that Take Part in the Decision 403 Making Process of the Population Towards Attitudes of Social Commitment

Anna M. Gil-Lafuente, $M^{a}$ Luisa Solé Moro

Impact of Campaigns for the Prevention of Alcohol Abuse in Adolescence

Agustí Casas Romeo, Rubén Huertas García, Ester Subirà Lobera 
Model of Hierarchical Structuring Variables of Exporting Companies

Joel Bonales Valencia, Juan Gaytán Cortés, José Sánchez Gutiérrez.

The Optimization in Pos Advertising through a Fuzzy Model based on the Application of Neuromarketing Techniques Jaime Gil-Lafuente, Josep María Tortosa Vidal, Jordi Aymerich Martínez.

Business Modelling for e-CRM Systems: Applying UML Specifications

Calin Gurau

Media Audiences Prediction: A Model Anna M. Gil-Lafuente, Luis Amiguet Molina

\section{PART 5: ECONOMICS AND POLITICS}

Imprecise Probability for Estimated Forecasting Variants of the

Economical Development G.C. Imanov, H.S. Aliyeva, R.A. Yusifzade

Modelling of Economic Risk and Uncertainty in Large Infrastructure Projects

Hans Schjaer-Jacobsen

Linguistic Approach for Evaluating Basic Needs Dissatisfaction

Luisa L. Lazzari, María J. Fernández.

Causal Structure and Systemic Approach in Economics Pablo S. García

Based Presentation of Macroeconomic Systems Evolution Leonid A. Kuznetsov

Chaotic Dynamics and Macroeconomics Shock Amplification 
Approximation to the Theory of Affinities to Manage the Problems of the Grouping Process

Anna M. Gil-Lafuente, Anna Klimova

Modelling of Selected Economic Time Series using the N-Regime Models

Anna Petrickova, Jana Lencuchova

Macroeconomic Flows in CEFTA Countries

Milica Bulajic, Dragana Kragulj, Sandra Jednak

Decision Making with the Generalized Probabilistic Weighted Averaging Distance Operator José M. Merigó, Montserrat Casanovas

Simulation Approach to Testing Regime-Switching Models for Slovak Alpine River Flows Magda Komornikova, Danusa Szokeova, Jozef Komornik

\section{PART 6: APPLICATIONS IN ENGINEERING}

Decision Support Model for Early Alert of Meteorological Severe Events

Alaín Calzadilla Rivero, José A. Díaz Batista

Symbolic Computations in Design and Modelling of Nonlinear Control A.A. Dyda, E.V. Lubimov, S. Di Gennaro

Fuzzy and PID Controls of FES-Assisted Walking with Body Weight 581 Transfer: Simulation Studies

R. Jailani, M.O. Tokhi, S.C. Gharooni

Modelling, Simulation and Power Management of a Stand-Alone 
Towards a Framework for Road Network Vulnerability Assessment

Sjoerd Mevissen, Edwin Dado

Digital Controller Modelling, Simulation and Design using Logic

605

Neural Networks

Monica Leba, Emil Pop

The Influence of Barrel Rifling Twist on the Stability of a Projectile Iyd Eqqab Maree

The Effect of Space Environments Factors on Spacecraft Structure Safeen Yaseen Ezaldeen

Thermomecanical Treatment of 7020 A1 Alloy

Shawnim R. Jalal

Agent-Based Tempermod Approach for Applicants Character

Recognition

Ieva Lauberte, Egils Ginters

$5 \mathrm{~Gb} / \mathrm{s}$ Low-Noise and High Bandwitdth $0.35 \mu \mathrm{m}$ CMOS

Transimpedance Amplifier

Escid Hammoudi, Attari Mokhtar

Support Vector Machine for Modelling Design Parameters in

Circular and Triangular Microstrip Patch Antennas

M. Cacciola, G. Megali, S. Calcagno, M. Versaci,

F.C. Morabito

Parallel-Hierarchical Transformation as the System Model of

Effective Artificial Intelligence Tools

L.I. Timchenko, N.I. Kokriatskaia, I.D. Ivasyuk,

G.L. Kosenko, R.V. Makarenko

Spring Brake Orthosis for FES-Assisted Walking with Wheel Walker

R. Jailani, M.O. Tokhi, S.C. Gharooni 
Towards an Advanced Virtual Testing Environment for Concrete

Materials

Edwin Dado, Eddie Koenders, Sjoerd Mevissen

Modelling, Simulation and VHDL Implementation of Distributions

Based PWM Controller

Emil Pop, Monica Leba

Fundamental Matrix Approach in Solving Practical Stability for

Distributed Parameter Systems

Djordje N. Dihovicni, Miroslav Medenica

Hybrid Modelling of Capillary Distribution System in the Food

Chain of Different Locations South of Bogota

Oscar Javier Herrera Ochoa

Modelling and Simulation as Integrated Tool for Research and

Development

Florin Ionescu

\section{PART 7: APPLICATIONS IN OTHER FIELDS}

Approach of Evaluation of Environmental Impacts using

Backpropagation Neural Network

Jelena Jovanovic, Zdravko Krivokapic, Sabrija Ramovic, Aleksandar Vujovic

Projecting Demographic Scenarios for a Southern Elephant Seal

Population

Mariano A. Ferrari, Claudio Campagna, Mirtha N. Lewis

Effect of Heat Input and Environmental Temperature on the Welding

Residual Stresses using ANSYS APDL Program Comparison with

Experimental Results

Nazhad A. Hussein 
Sphalerite Dissolution Activity in the Presence of Sulphuric Acid by using the Pitzer's Model

Begar Abdelhakim, M.A. Djeghlal, A. Begar, A. Douair

Fast Fourier Transform Ensemble Kalman Filter with Application to a Coupled Atmosphere-Wildland Fire Model

Jan Mandel, Jonathan D. Beezley,

Volodymyr Y. Kondratenko

Magnetic Field Effect on the Near and Far Cylinder Wakes

M. Aissa, A. Bouabdallah, H. Oualli

Stability Theory Methods in Modelling Problems

Lyudmila K. Kuzmina 